\title{
TURKISH MERGERS AND ACQUISITIONS (M\&As): A HISTORICAL VIEW OF CHARACTERISTICS, TRENDS, AND DIRECTIONS
}

\author{
Omer Faruk GENC, PhD \\ Youngstown State Uni., Williamson CBA, (ofgenc@ysu.edu) \\ Burak KALKAN \\ Abdullah Gül Uni., School of Managerial Sciences, Kayseri, Turkey, (burak.kalkan@agu.edu.tr)
}

\begin{abstract}
This study analyses acquisitions that Turkish companies are involved between 19902017 by analyzing trends in number and volume of activity, geographic dispersion of foreign acquirers and targets, deal characteristics. We also group acquisitions into three according to the home country of acquirers and targets and compare. As being the first study to analyze all three groups at the same time and having the most comprehensive sample in terms of period, this study contributes to the literature by providing a detailed and comprehensive understanding of Turkish M\&As. We finally discuss implications for firms and policymakers while providing insights for future research.
\end{abstract}

Keywords: Mergers and Acquisitions, Turkish Acquisitions, M\&A Characteristics.

\section{TÜRK SATIN ALMA VE BİRLEŞMELERİ (S\&B): S\&B ISSLEMLERININ KARAKTER, TREND VE YÖNELIME GÖRE INCELENMESI}

\begin{abstract}
ÖZET
Bu çalışmada, Türk şirketlerinin dahil olduğu 1990-2017 yılları arasında gerçekleşen şirket $S \& B$ işlemleri analiz edilmektedir. Çalışmamızda, Türk şirket $S \& B$ işlemlerinin sayı ve değer bakımından tarihsel trendini, ülkelerin coğrafi dă̆ılımlarını ve S\&B’lerin sektör, ilişki, işlem hacmi, vb. özelliklerini içeren genel ve kapsamlı bir profilini çiziyoruz. S\&B işlemlerini alıcı ve satıcıların ülkelerine göre 3 gruba ayırıyor ve bu grupları karşılaştırıyoruz. Çalışmamız. üç grup satın almanın karşılaştırıldı ̆̆ ilk çalışma olması ve Türk şirket satın almalarıyla ilgili yapılan çalışmalar içerisinde en geniş dönemi kapsamasından dolayı literatüre önemli katkılar sunmaktadır. Son olarak, firmalar ve politika yapıcılar için çıkarımlar tartışılmakta ve ileri çalışmalar için fikirler verilmektedir.
\end{abstract}

Anahtar Kelimeler: Şirket Satın Alma ve Birleşmeleri, Türk Satın Almaları, Sirket Satın Alma Özellikleri. 


\section{Introduction}

Mergers and Acquisitions (M\&A) have been used by firms extensively as a growth strategy and as a mode for internationalization. Given the high use and importance of the phenomena, numerous studies have been conducted about M\&As in various fields including finance, management, accounting, etc. (e.g. Schiffbauer et al, 2017; Fang et al, 2017; Banerjee \& Nayak, 2015; Gregory \& O'Donohoe, 2014). With the globalization and the greater involvement of emerging markets in international business, more M\&As take place in those regions. These M\&As include both transactions that done by emerging market multinationals as well as the emerging market companies acquired by firms from developed markets. This trend has created an attention to the M\&As in emerging markets. Majority of these studies are conducted in Chinese or Indian context, and other smaller emerging markets like Turkey has not received enough attention. However, Turkey, as a bridge between east and west, has characteristics of both the European and Asian sides, and is a great context to study M\&As.

Turkey, as one of the fastest growing emerging markets in the world, has seen a dramatic increase in M\&A activity as well. There has been a great transformation in the Turkish economy after the devastating economic crisis in 2000-2001, which resulted in greater exports/ imports and capital flows in and out of Turkey (Yıldırım, 2017). Capital inflows to Turkey in terms of M\&As has been one of the major drivers of economic growth in Turkey. Moreover, several Turkish companies have engaged in M\&As to enter new markets, which also makes this phenomenon very important for Turkish firms and policymakers.

Despite the critical role it plays for the Turkish economy and firms, there have been very few studies that examine the Turkish M\&As mainly due to the difficulties in accessing M\&A data. These studies, which will be discussed in more detail at the following section, have used either single cases or small samples of Turkish M\&As (Turgay et al, 2014; Semerciöz \& Çakınberk, 2003; Genç \& Coşkun, 2013; Akben et al, 2011). Although these studies provide good insights about the Turkish M\&As, they do not allow us to see the big picture about these M\&As. Moreover, there are different groups of acquisitions that Turkish companies are involved in terms of the home country of acquirer or target. But, the studies in existing studies often focused on one group and are not comprehensive in that sense. These create a need for a study that looks at the Turkish M\&As in a comprehensive way in terms of both the types of M\&As and timeframe. Our goal is to fill this gap by examining all M\&As that took place in Turkey between 1990 and 2017. This will allow us to the general picture about Turkish M\&As in a detailed way.

We examined Turkish acquisitions from several perspectives and compared them in terms of three groups; (1) acquisitions of Turkish companies by foreign acquirers, (2) Turkish companies`acquisitions of foreign targets, and (3) acquisitions within Turkey where both acquirer and target are Turkish firms. First, our results indicate a great increase in both the number and value of acquisition activity in Turkey. This is a good sign for both capital inflows to Turkey and the internationalization of Turkish companies via foreign acquisitions. We observed a greater acquisition activity of Turkish companies by foreign companies compared to Turkish acquisition of the foreign target. So, the capital inflow is greater than capital outflow in terms of acquisitions. Purely domestic acquisitions are greater than acquisitions by Turkish 
companies but less than acquisitions by foreign companies. We also examined the specific characteristics of Turkish acquisitions. Manufacturing, finance, insurance, transportation, energy is among the most popular sectors for Turkish acquisitions. However, there are very few high-tech acquisitions, which implies a problem for the health of the Turkish economy with very few high-value-added companies involved in acquisition activity. We also found that Turkish companies do not often use adviser in the acquisition process, which we see as a problem and managerial implication. With regard to the regions, Europe dominates both foreign acquirers and foreign targets of Turkish companies. Although the domination of Europe is higher for Turkish acquisition of foreign targets, we observed a more diverse picture in terms of having more target companies from developing countries. another important difference between these two types of acquisitions was about North America and the US particularly. The US is at the top of the list in the countries that acquire Turkish companies, but there was almost no US target firm that acquired by Turkish firms. That shows the geographic distributions of foreign acquirers of Turkish companies and foreign targets that Turkish companies acquire are not the same. Another important finding about regions was the high number of foreign acquirers interested in Turkish companies although it was the opposite in terms of foreign targets for Turkish acquirers.

This study contributes to the literature in several ways. First, our study is the most comprehensive in terms of the type of acquisitions and the period in the context of Turkey. This enables us to see the big picture over time about Turkish M\&As. Secondly, different from the prior literature, we look at all three types of acquisitions that take place in Turkey, which allows us to make comparisons between them. We showed that there are differences between the types of acquisitions that Turkish companies are involved. We believe that by providing a comprehensive picture of Turkish M\&As, this study will open new avenues of research in this understudied phenomenon in Turkey as well as providing implications for policy-makers.

The rest of the paper proceeds as follows: In the next section, we conduct a literature review about M\&As with a particular focus on Turkish M\&As. The findings of the study are presented in the following section. Then, we conclude the paper with the discussion, which includes managerial, policy, and theoretical implications, and suggestions for future research.

\section{Literature Review}

Companies use mergers and acquisitions extensively as a strategic tool to grow and compete. The number of M\&As peaked in 2007 (UNCTAD, 2008). Despite a decline after the global financial crisis, both the number and the volume of M\&As have increased again in recent years with more than half of the transaction to be at the international level. Consistent with the use of them, M\&As have received great attention in the literature. Although there are studies that found a positive effect of M\&As (Chari et al, 2010; Tao et al, 2017), the majority of studies view M\&As as detrimental to the firm performance acquisitions (Agrawal et al, 1992; Billet \& Qian, 2008; Spyrou \& Siougle, 2007). Increase use of M\&As despite the high failure rates creates a paradox in the understanding of M\&As (Genç, 2016). Agency problems (Kogut \& Zander, 1993), CEO overconfidence (Malmendier \& Tate, 2008), information asymmetry (Fu et al, 2013) are among the factors that have been used to explain the failure in acquisitions. There is also variation in the outcomes of them depending on the type of acquisitions. For instance, 
Genc \& Zakaria (2017) made a distinction between domestic and international acquisitions and found that domestic acquisitions perform better than international ones.

M\&As have been traditionally been studied from at the developed country context as most of them used to take place in those regions. There has been greater interest in M\&As from emerging markets and several studies have examined acquisitions in emerging markets mainly China and India. Turkey, although being an attractive location for international acquisition activity, has not received enough attention in the literature. In one of the most recent studies about Turkish M\&As, Yıldırım (2017) looked at the acquisitions done by Turkish companies and provided the characteristics of these acquisitions. Akdoğu (2011) is another important study that provides a general picture of Turkish M\&As for 1988-2008 period. Several other studies about Turkish M\&As are conducted based on case studies (e.g. Turgay et al, 2014; Semerciöz \& Çakınberk, 2003; Ateşoğlu et al, 2016), and it is hard to make generalizations about Turkish M\&As based on these studies.

There are also other studies that examine the Turkish M\&As at the firm level. Çelikyurt \& Dönmez (2016) is one of the very few studies that look at the issue at the firm level. They focused on the Turkish firms that went to an IPO and examined their acquisition behavior after the IPOs. Similarly, Günay Bendaş (2015) examined the firm level market returns for Turkish acquirers and found a significant long-term effect of acquisitions on market returns. However, this study was based on the domestic acquisition in 2013 and have limited generalizability. Similar studies conducted for different time horizons to see the market reactions to Turkish acquisitions (e.g. Genç \& Coşkun, 2013; Akben \& Altık, 2011). Some other studies examined Turkish M\&As in one industry sector. Many of these studies focused on the acquisitions in Turkish banking sector (e.g. Şahin \& Doğukanlı, 2015; Aksoy, 2013).

Although the market reaction is the main tool that has been used to assess the outcomes of Turkish M\&As, financial outcomes can also be used to assess the outcome of Turkish acquisitions. For instance, Ilarslan \& Aşıkoğlu (2012) investigated 17 acquisitions by Turkish public firms in 2004-2005 and found evidence about positive improvements in the financial performance of these acquirers. Different from majority of the literature that focused on one type of acquisition, Akdoğu (2012) compared acquisitions done by foreign vs domestic acquirers in terms of their financials for the 1998-2008 period. The success factors are another important stream of literature about M\&As, but there have been very few studies about them in Turkey (e.g. Dalkılıç \& Cagle, 2015).

Although there has been an increase in the studies that look at Turkish M\&As, we still do not have a good understanding of them. Due to the difficulty of data gathering in the Turkish context, the majority of the studies use small samples for limited periods or case studies. None of these allows us to see the trends and the big picture about Turkish acquisitions. Given the increase in Turkish M\&As, there is also a need for a study that includes most recent M\&A activity in Turkey. Moreover, only a group of M\&As (either by Turkish or foreign acquirers) are used in most of these studies. In this paper, we aim to fill this gap by examining all types of acquisitions that took place in Turkey between 1990 and 2017. By this way, we want to provide a comprehensive picture of the Turkish M\&As. 


\section{Findings}

\subsection{Data and Sample}

The M\&A data used in this study comes from the Thomson Financial Securities Data's Worldwide M\&A Database called Securities Data Corporation (SDC) Platinum. The sample covers all completed deals that include a Turkish company during the years 1990-2017. There are three groups of acquisitions that we analyze in this study. Group 1 consists of acquisitions of Turkish companies by foreign acquirers. In group 2, we have acquisitions of foreign targets by Turkish companies. We classified the domestic acquisitions where both acquirer and target are Turkish companies as group 3. The number of acquisitions in each group can be seen in Table 1. Domestic acquisitions constitute more than half of our sample with $57.4 \%$, which is followed by acquisitions of Turkish companies by foreign acquirers (34.7\%). We have also 122 cases where Turkish companies acquire foreign targets. Based on these numbers, it is important to note that acquisitions of Turkish companies by foreign acquirers are far greater (almost 5 times) than Turkish companies acquisitions of foreign companies.

Table 1: Number of Acquisitions by Group

\begin{tabular}{clcc}
\hline & \multicolumn{1}{c}{ Type of Acquisition } & Number & Percent \\
\hline Group 1 & Turkish Target - Foreign Acquirer & 537 & 34.71 \\
\hline Group 2 & Foreign Target - Turkish Acquirer & 122 & 7.89 \\
\hline Group 3 & Turkish Target - Turkish Acquirer & 888 & 57.4 \\
\hline Total & All Acquisitions & 1.547 & 100 \\
\hline
\end{tabular}

\subsection{Acquisitions over Years}

We looked at the number of acquisitions of each group in the previous section, but it is also important to analyze the trends over years in terms of the number of acquisitions. Figure 1 presents both the total number and value of acquisitions in each group. Both the number and value of acquisitions were minimal in the 1990s, and we see an increase especially after 2004. The total value of acquisitions was the highest in 2005 and 2007. Despite a decline after the global financial crisis, the total value of acquisitions has been high since then. Group 1 and 3 constitute most of the acquisitions in terms of the volume of deals. These two groups are very close by the amount of money involved in these acquisitions. However, with regard to the number of acquisitions, group 3 (domestic acquisitions) is the highest followed by acquisitions of Turkish companies by foreign acquirers. As we can see in Figure 1, the number and volume of acquisitions do not go hand in hand all the time. 2005-2007 is the most active period in terms of the value of all acquisitions whereas 2015 is the peak for the number of acquisitions. In sum, both figures indicate that the M\&A activity has increased a lot compared to the 1990s. Foreign acquisition of Turkish companies constitute a significant portion of M\&A activity in terms of value and purely domestic acquisitions constitute the majority of acquisitions in terms of number. 
Figure 1: Turkish Acquisitions over Years

Figure 1a: Number of Acquisitions over Years

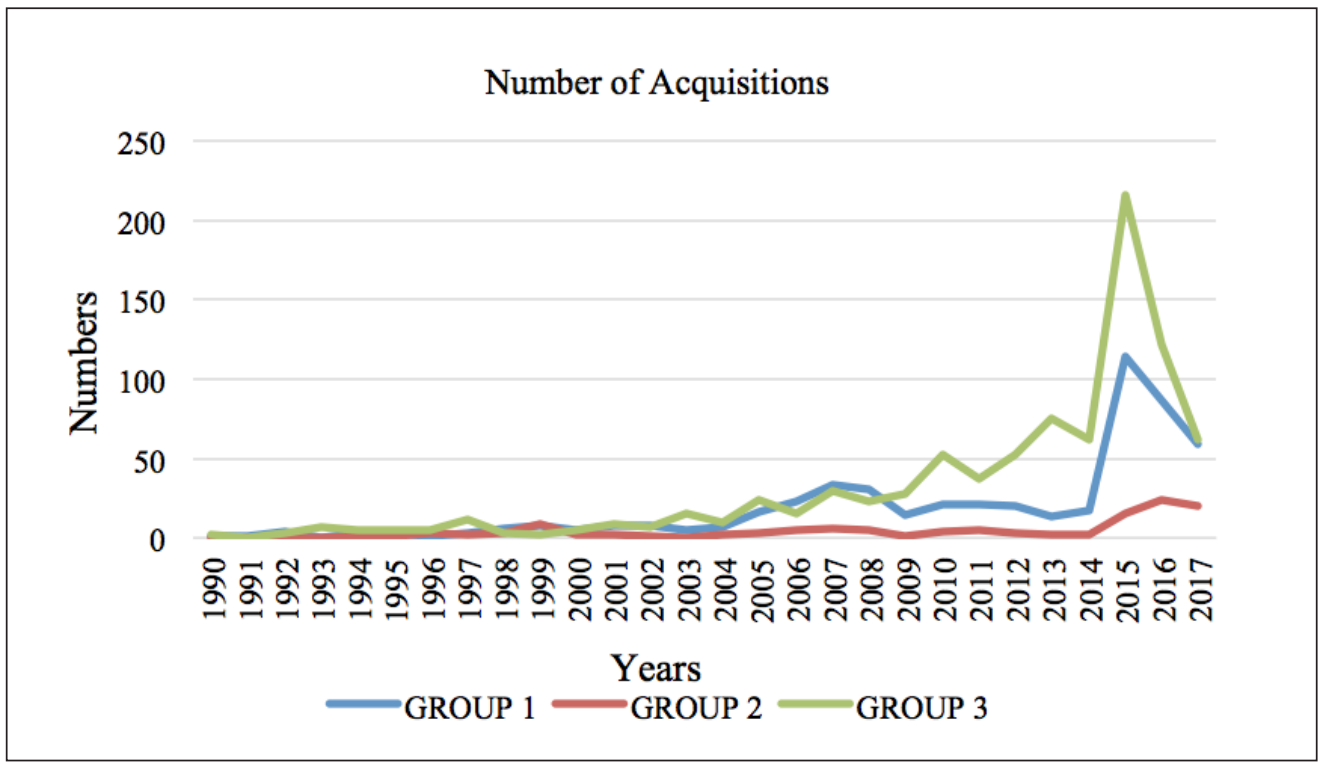

Figure 1b: Value of Acquisitions over Years

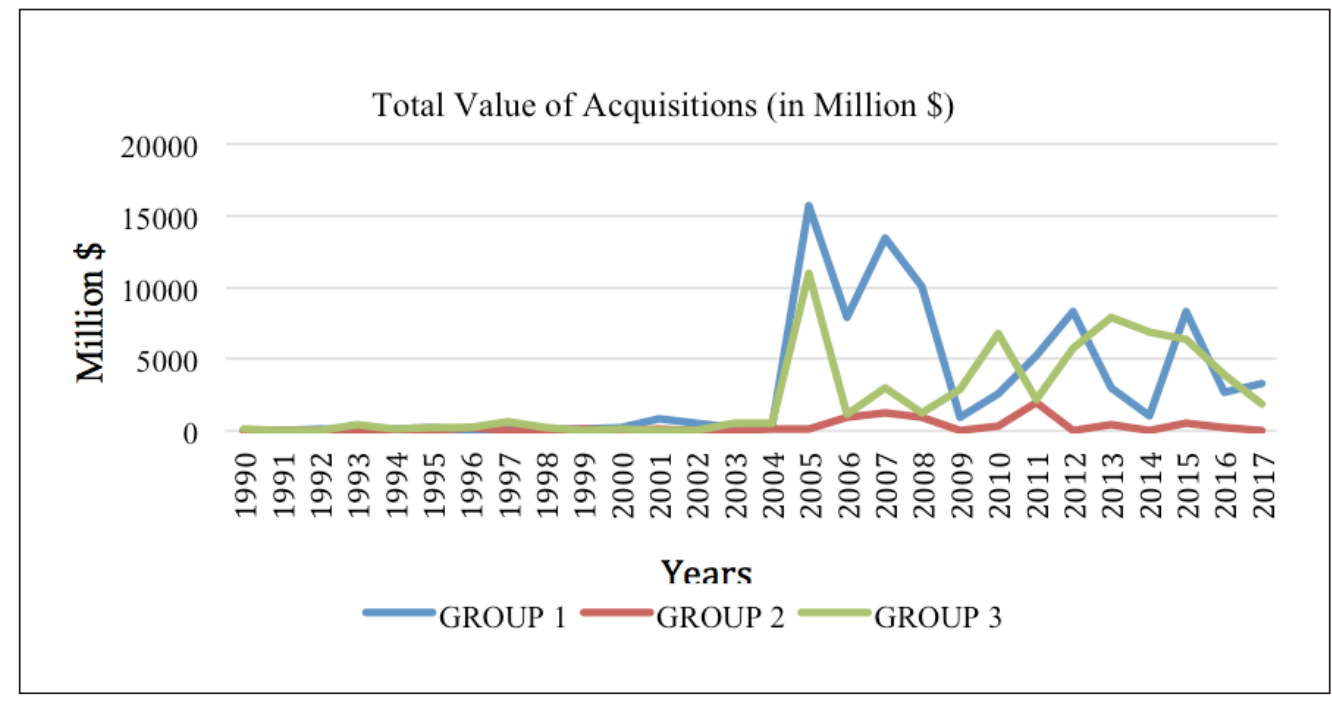




\subsection{Descriptive Statistics}

We examined the characteristic of all these acquisitions in detail to see the overall picture of the M\&A activity of Turkish companies. First, we analyzed the general characteristics of these acquisitions, which we present at Table 2. The average size of all acquisitions is 133.3 million dollars. However, there is variation between different groups in terms of the deal size. Group 1 acquisitions are the largest with an average deal size of 241.5 million dollars. On the other hand, group 2 and 3 have very similar acquisition size of 94 and 86 million dollars respectively. When we look at the new enterprise value after the acquisition, we see a similar picture where group 1 is the largest by far and group 2 and 3 have similar sizes. Most of the deals in our sample of majority acquisitions where on average $70 \%$ of target is acquired and $80 \%$ of target is owned after the acquisitions. We have very similar values for all three types of acquisitions in that matter.

\section{Table 2: Descriptive Statistics}

\section{Panel A: All Acquisitions}

\begin{tabular}{lccc}
\hline & $\mathbf{N}$ & Mean & Std. Dev. \\
\hline Value of Transaction & 1.186 & 133.30 & 436.47 \\
\hline$\%$ of Shares Acquired & 1.281 & 71.30 & 32.69 \\
\hline$\%$ Owned after Transaction & 1.281 & 79.54 & 28.06 \\
\hline New Enterprise Value & 857 & 347.51 & 1582.36 \\
\hline
\end{tabular}

\section{Panel B: Turkish Target - Foreign Acquirer}

\begin{tabular}{lccc}
\hline & N & Mean & Std. Dev. \\
\hline Value of Transaction & 356 & 241.52 & 653.03 \\
\hline$\%$ of Shares Acquired & 416 & 72.05 & 29.96 \\
\hline$\%$ of Owned after Transaction & 416 & 79.76 & 26.45 \\
\hline New Enterprise Value & 266 & 748.64 & 2621.91 \\
\hline
\end{tabular}

\section{Panel C: Foreign Target - Turkish Acquirer}

\begin{tabular}{lccc}
\hline & N & Mean & Std. Dev. \\
\hline Value of Transaction & 80 & 94.92 & 219.28 \\
\hline$\%$ of Shares Acquired & 106 & 75.48 & 29.08 \\
\hline \% of Owned after Transaction & 106 & 82.54 & 24.76 \\
\hline New Enterprise Value & 52 & 120.80 & 198.02 \\
\hline
\end{tabular}

\section{Panel D: Turkish Acquirer - Turkish Target}

\begin{tabular}{lccc}
\hline & N & Mean & Std. Dev. \\
\hline Value of Transaction & 750 & 86.03 & 293.68 \\
\hline$\%$ of Shares Acquired & 759 & 70.30 & 34.53 \\
\hline \% of Owned after Transaction & 759 & 79.00 & 29.33 \\
\hline New Enterprise Value & 539 & 171.42 & 691.68 \\
\hline
\end{tabular}




\subsection{Deal Characteristics}

We examine characteristics of the Turkish acquisitions more detailed in this section, which are presented in Table 3. The first variable we analyze is the relatedness. We classify acquisitions as related if the acquirer and target are from the same industry at 4-digit Standard Industrial Classification (SIC) level. On overall, 31.09\% of Turkish acquisitions are related. The rate is similar in all groups while a little bit higher in group $1(35.20 \%)$ and lower in group $3(27.82 \%)$. Next variable we examined is whether the acquirer or target is from a high tech industry. $10.55 \%$ of all acquirers and $11.92 \%$ of all targets are from high-tech industries. This is a very low rate and indicates that there are few companies in the Turkish acquisition market from high-tech industries. The rate of high-tech companies is slightly higher in group 1 . This indicates that there are more high-tech companies, which engage in acquisitions by foreign companies compared to other types of acquisitions. The last variable we look in this section is the use of advisor in the acquisition process. On average, $16.03 \%$ of all acquirers and $20.62 \%$ of all targets in our sample work with an advisor. These rates are relatively low compared to the rates in developed countries. With regard to the comparison of types of acquisitions, we see the highest use of advisors in acquisitions of Turkish companies by foreign companies. That's expected as these are larger acquisitions.

Table 3: Deal Characteristics*

\begin{tabular}{lcccc}
\hline & All & Group 1 & Group 2 & Group 3 \\
\hline Relatedness & 31.09 & 35.2 & 36.89 & 27.82 \\
\hline High-tech Acquirer & 10.55 & 13.25 & 9.09 & 9.12 \\
\hline High-tech Target & 11.92 & 13.86 & 9.92 & 11.04 \\
\hline Adviser use - Acquirer & 16.03 & 25.69 & 16.39 & 10.13 \\
\hline Adviser use - Target & 20.62 & 24.39 & 22.95 & 18.01 \\
\hline
\end{tabular}

* Number represent percentages

\subsection{Acquisitions over Sectors}

In this section, we analyze acquisitions in terms of the sector that acquirer and target operates. We want to see which sectors are most active in Turkish acquisitions. As can be seen in Table 4, the majority of the foreign firms that acquire Turkish companies are from manufacturing, finance, insurance and real estate industries. If we look at the target Turkish companies that these foreign companies acquire, we see a slightly different picture. Manufacturing companies are still dominant in target companies with $34.45 \%$. However, the percentage of companies from finance, insurance and real estate is a lot lower compared to the percentage of acquirers. This implies that many acquirers from the finance and banking industries acquire Turkish companies just for investment. Transportation and other service sectors seem to be the most popular after the manufacturing in terms of Turkish targets.

When we look at the acquisition in group 2, we find that finance, manufacturing and transportation sectors dominate the Turkish companies that acquire foreign targets with percentages of $36.07,27.87$ and 13,93 respectively. This picture is very similar to the acquisitions in Group 1. However, the distribution of target companies that Turkish 
companies acquire is very different from Turkish acquirers. The rate of companies from the manufacturing sector is higher in target companies (38 vs. 27\%). The same situation applies to the transportation, communication, electric and gas sector (21 vs. $13 \%)$. On the other hand, the finance and insurance sector constitutes $38 \%$ of Turkish acquirers, but only $17 \%$ of targets acquired by these Turkish companies. This implies that Turkish companies target unrelated foreign companies as well. We see a similar pattern in domestic acquisitions (group 3) as the rates of firms from finance and insurance is lower in targets compared to the rate in acquirers. These findings imply that there are many unrelated acquisitions in Turkey and acquirers from the finance and insurance sector engage in acquisition in other sectors.

Table 4: Industry Classification of Acquirers and Targets

\section{Panel A: Industry Classification of Acquirers}

\begin{tabular}{lcccc}
\hline Industry & $\begin{array}{c}\text { All } \\
\text { Acquisitions }\end{array}$ & Group 1 & Group 2 & Group 3 \\
\hline Agriculture, Forestry \& Fishing & $0.78 \%$ & $0.74 \%$ & $0.00 \%$ & $0.90 \%$ \\
\hline Mining & $4.40 \%$ & $6.33 \%$ & $4.92 \%$ & $3.15 \%$ \\
\hline Construction & $3.17 \%$ & $0.00 \%$ & $6.56 \%$ & $4.62 \%$ \\
\hline Manufacturing & $26.76 \%$ & $29.42 \%$ & $27.87 \%$ & $25.00 \%$ \\
\hline $\begin{array}{l}\text { Transportation, Communications, } \\
\text { Electric, Gas \& Sanitary Services }\end{array}$ & $12.73 \%$ & $7.26 \%$ & $13.93 \%$ & $15.88 \%$ \\
\hline Wholesale Trade & $3.75 \%$ & $4.10 \%$ & $4.10 \%$ & $3.49 \%$ \\
\hline Retail Trade & $2.39 \%$ & $0.56 \%$ & $1.64 \%$ & $3.60 \%$ \\
\hline Finance, Insurance \& Real Estate & $36.26 \%$ & $38.18 \%$ & $36.07 \%$ & $35.14 \%$ \\
\hline Services & $9.11 \%$ & $11.92 \%$ & $4.92 \%$ & $8.00 \%$ \\
\hline Public Administration & $0.65 \%$ & $1.49 \%$ & $0.00 \%$ & $0.23 \%$ \\
\hline
\end{tabular}

Panel B: Industry Classification of Targets

\begin{tabular}{lcccc}
\hline Industry & $\begin{array}{c}\text { All } \\
\text { Acquisitions }\end{array}$ & Group 1 & Group 2 & Group 3 \\
\hline Agriculture, Forestry \& Fishing & $1.42 \%$ & $1.68 \%$ & $0.00 \%$ & $1.46 \%$ \\
\hline Mining & $5.49 \%$ & $8.94 \%$ & $6.56 \%$ & $3.27 \%$ \\
\hline Construction & $1.29 \%$ & $0.93 \%$ & $2.46 \%$ & $1.35 \%$ \\
\hline Manufacturing & $31.29 \%$ & $34.45 \%$ & $38.52 \%$ & $28.38 \%$ \\
\hline $\begin{array}{l}\text { Transportation, Communications, } \\
\text { Electric, Gas \& Sanitary Services }\end{array}$ & $21.53 \%$ & $13.41 \%$ & $21.31 \%$ & $26.46 \%$ \\
\hline Wholesale Trade & $4.59 \%$ & $4.10 \%$ & $2.46 \%$ & $5.18 \%$ \\
\hline Retail Trade & $4.78 \%$ & $2.98 \%$ & $4.92 \%$ & $5.86 \%$ \\
\hline Finance, Insurance \& Real Estate & $16.22 \%$ & $17.13 \%$ & $13.93 \%$ & $15.99 \%$ \\
\hline Services & $13.32 \%$ & $16.39 \%$ & $9.02 \%$ & $12.05 \%$ \\
\hline Public Administration & $0.06 \%$ & $0.00 \%$ & $0.82 \%$ & $0.00 \%$ \\
\hline
\end{tabular}




\subsection{Acquisitions over Regions}

Last analysis we conducted is about the regions of acquisitions. We examined both the nationalities of foreign firms that acquire Turkish targets and foreign firms acquired by Turkish companies. First, we look at the firms` home countries in terms of development level, which are presented in Table 5.72.25\% of foreign acquirers of Turkish companies are from developed countries whereas $16.57 \%$ are from developing economies. We can say that Turkish companies are targets of acquirers mostly from developed countries. With regard to the countries of targets that Turkish companies acquire, developed countries still constitute the majority, but with a lower percentage (61.48). So, the role of developing economies is higher for Turkish companies' acquisitions compared to the acquisition of Turkish companies by foreign acquirers. When we go into more detail and examine the regions of foreign acquirers and targets, Europe dominates both of the samples. 52.14\% of foreign acquirers are from Europe. We also have acquirers from North America (16.01\%), Asia (11.55\%) and Middle East (8.94\%). Therefore, half of the foreign acquirers are from Europe and the rest are from mainly three regions specified above. Europe has a much dominant role in the foreign targets that Turkish companies acquire. $70.49 \%$ of foreign targets are from Europe. Turkish companies also have acquisitions in Asia (14.75\%), Middle East (7.38\%) and Africa (4.92\%).

The nationalities of foreign acquirers and targets are listed in Figure 2. Although Europe as a region constitutes half of the foreign acquirers of Turkish companies, when we look at the country level, the US has the most acquisition of Turkish companies. Developed countries from Europe such as the UK, Netherlands, Germany, and France follow the US in terms of having the highest number of Turkish acquisitions. The distribution of countries in terms of foreign targets is more diverse. Turkish companies still acquire many companies from Europe, but different from foreign acquirers, we see many developing countries as targets of Turkish acquirers such as Romania, Bulgaria, and Hungary.

Table 5: Acquisitions over Regions

\begin{tabular}{lcc}
\hline Panel A: Development Level & & \\
\hline & Acquirer* & Target** \\
\hline Developed & $72.25 \%$ & $61.48 \%$ \\
\hline Developing & $16.57 \%$ & $15.57 \%$ \\
\hline Transition & $2.98 \%$ & $22.95 \%$ \\
\hline Panel B: Regions & & \\
\hline & Acquirer & Target \\
\hline Africa & $1.86 \%$ & $4.92 \%$ \\
\hline America & $0.37 \%$ & $0.00 \%$ \\
\hline Asia & $11.55 \%$ & $14.75 \%$ \\
\hline Australia & $0.74 \%$ & $0.82 \%$ \\
\hline Europe & $52.14 \%$ & $70.49 \%$ \\
\hline Latin America & $0.93 \%$ & $0.00 \%$ \\
\hline Middle East & $8.94 \%$ & $7.38 \%$ \\
\hline
\end{tabular}

* Represents foreign firm that acquirer Turkish companies

** Represents foreign targets acquired by Turkish companies 
Figure 2: Acquisitions over Countries

Figure 2a: Foreign Acquirers` Home Countries

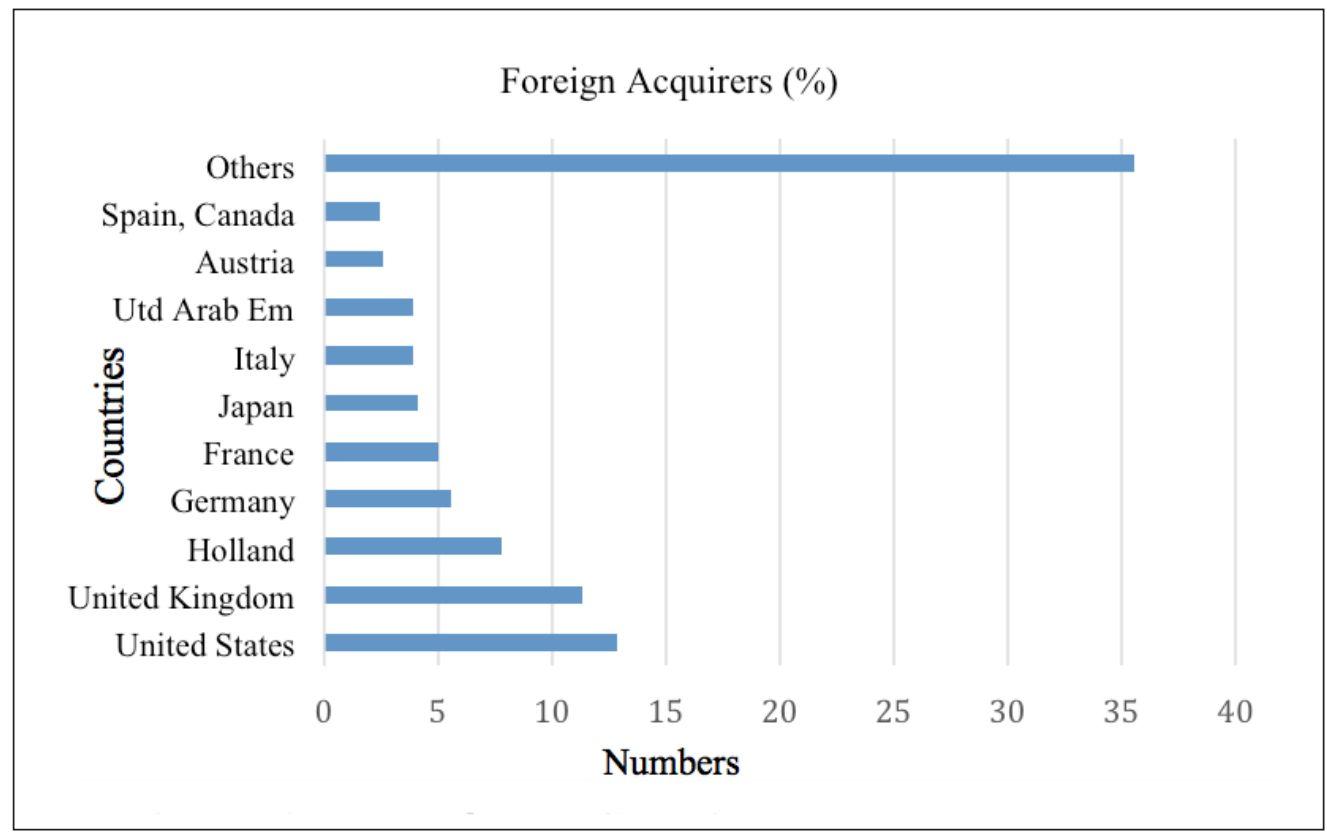

Figure 2b: Foreign Targets`Home Countries

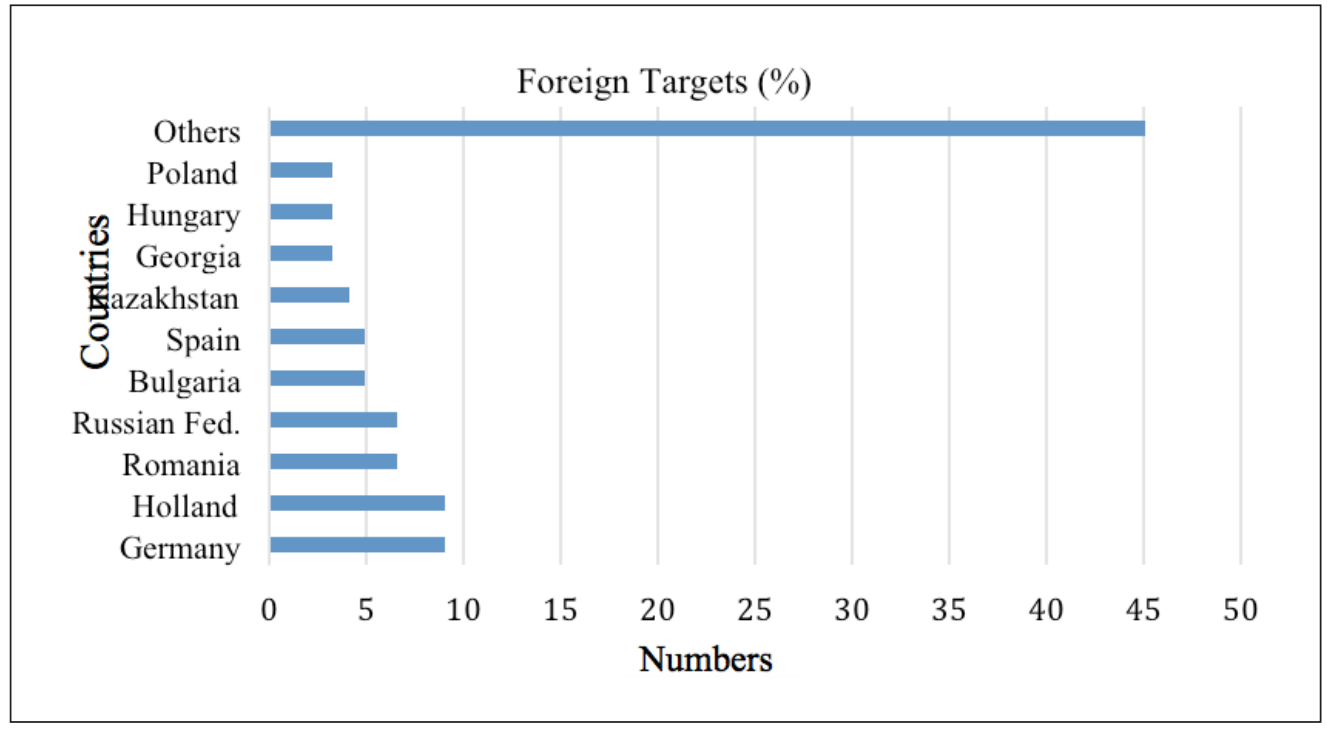




\section{Discussion}

Scholars from multiple fields, including management, finance, and economics have shown increasing interest in acquisitions, which is consistent with the increasing use of them. The world M\&A picture is changing in favor of emerging markets as more M\&A activity is happening in those markets. Despite the huge interest in M\&As from emerging markets, most studies in the literature focus on China or India, and the M\&As from Turkey has been understudied. The studies that have looked at Turkish M\&As have usually used case studies or samples that are limited to a short period or a specific industry. That creates a need for a better understanding of the real and comprehensive picture of Turkish M\&As.

In this study, we analyze all the M\&As that a Turkish company is involved either as a target or an acquirer for the period between 1990 and 2017. We classify acquisitions into three groups in terms of acquirer and target home countries. According to our findings, purely domestic acquisitions (group 3) constitute more than half of all Turkish acquisitions. However, we also see high number of foreign firms acquiring Turkish firms (Group 1). Compared to the other two groups, the number of acquisitions where a Turkish company acquires a foreign company (group 2) is low. With regard to the trend over years, we observe a tremendous increase of M\&A activity in Turkey after 2004 in terms of both number and value of acquisitions. This is a good indicator with regard to the capital inflow to Turkey, but Turkish companies are not that successful with regard to the internationalization via acquisitions. In general, historical trends imply that Turkish companies are much more involved in M\&As both in Turkey and worldwide.

When we look at the specific deal characteristics of the acquisitions, we found that there are very few high-tech firms in these M\&As. This reflects the overall structure of the Turkish economy. However, the rate of high-tech firms is higher in foreign acquisitions, which shows the importance of these firms. High-tech firms attract more investment from foreign firms. Despite the increase in number of acquisitions of Turkish acquirers, the foreign acquisitions of Turkish companies are larger on average. This again implies that Turkish companies are not active enough to engage in large international acquisitions. We also examined the geographic distribution of acquisitions. Europe is the dominant region in both foreign acquirers that acquire Turkish firms and foreign targets that Turkish companies acquire. However, we realized some differences between these groups. Most of the acquirers of Turkish firms are from developed markets whereas we see more countries from developing regions that are targets to Turkish companies. Another interesting difference was the role of the US in Turkish acquisitions. As a country, the US is home to the highest number of acquirers that target Turkish firms, although Turkish companies have very little M\&A activity there.

This study contributes to the Turkish M\&A literature in an important way. To the best of our knowledge, this is first study that examines all three groups of acquisitions at the same time. In addition, our study is the most comprehensive in terms of the industries it covers and the period. That enables us to see the overall big picture about Turkish M\&A activity. We show that M\&A is an important phenomenon for Turkish companies and there is a need for a better understanding of them in terms of drivers, success factors, and outcomes. We hope to trigger research in this stream of literature. 
Our study also has important implications for both firms and policymakers. M\&As are used extensively by multinational corporations from different parts of the world. We see this trend in the foreign acquirers that target Turkish firms. However, our findings indicate that Turkish companies are not as aggressive as their counterparts from other countries are. However, acquisitions are the main tools to get resources that are difficult to generate (Gubbi et al, 2010). Turkish firms should be more pro-active and engage in international acquisitions in order to be global players in their industries. They should also diversify more in terms of targeting foreign markets outside the Europe. Another interesting finding of our study was about the use of advisors by acquirers and targets. Turkish companies use advisers less frequently compared to their counterparts in foreign markets. Turkish firms should not hesitate to invest in advising services to be more successful in M\&As both as a target and acquirer.

M\&A activities are important for the capital inflow and the well-being of the economy, which also creates implications for policy-makers. Despite the historical increase in M\&A activity in Turkey, there has been a decline in last two years, which is a concern. Policymakers should create incentives and lower the bureaucracy for both foreign firms who want to acquire Turkish companies and the Turkish companies who want to acquire foreign firms. That will boost the M\&A activity which is good for capital flows and the health of Turkish economy. It will also help Turkish firms in their internationalization process and enhance their competitiveness in international markets. The geographic dispersion of foreign acquirers is limited to few regions and policy-makers would create incentives and ways to attract more investment from emerging markets like China and India. These countries have invested heavily in world markets, but Turkey is not benefited much from these investments. So, we hope our study to shed light on Turkish M\&A phenomena and provide insights for both firms and policymakers.

\section{References}

Agrawal, A., Jaffe, J., \& Mandelker, G. (1992). The post-merger performance of acquiring firms: A re-examination of an anomaly. Journal of Finance, 47 (4), 1605-21.

Akben, Selçuk E., \& Altık, Yılmaz, A. (2011). The impact of mergers and acquisitions on acquirer performance: Evidence from Turkey. Business and Economics Journal.

Akdoğu, E. (2011). Türkiye'de 1988-2008 dönemindeki firma birleşmeleri, birleşme dalgaları ve genel tablo. Muhasebe ve Finansman Dergisi, 52, 137-152.

Akdoğu, E. (2012). 2005-2008 dönemi firma birleşmleri dalgasında yabancı ve yerli alıcı firma profilleri. Muhasebe ve Finansman Dergisi, 55, 51-70.

Aksoy, Muzaffer. (2013). The impact of organizational culture and learning capabilities on the effectiveness and the performance of cross border acquisitons. IIB International Refereed Academic Social Sciences Journal, 4(12), 133-152.

Ateşoğlu, Coşkun. S., \& Kargın, S. (2016). Sınır ötesi birleşme ve satın almaların bankalarınfFinansal performansına etkileri: Üç banka üzerinde CAMELS analiz. Muhasebe ve Finansman Dergisi, 69, 41-60.

Banerjee, T., \& Nayak, A. (2015). Comparing domestic and cross-border mergers and acquisitions in the pharmaceutical industry. Atlantic Economic Journal, 43(4), 489-499. doi:10.1007/s11293-015-9476-0 
Bendaş, G. (2015). The effects of acquisitions on firm value, evidence from Turkey. Dogus University Journal, 16(1): 79-90.

Billett, M., \& Qian, Y. (2008). Are overconfident CEOs born or made? Evidence of selfattribution bias from frequent acquirers. Management Science, 54(6): 1037-1051.

Chari, A., Ouiet, P., \& Tesar, L. (2010). The value of control in emerging markets. The Review of Financial Studies, 23(4): 1741-1770.

Çelikyurt, U., \& Dönmez, B. N. (2016). Mergers and acquisitions activity of initial public offerings firms on Borsa İstanbul. Electronic Journal of Social Sciences, 15(57): 719737.

Dalkılıç, A. F., \& Cagle, M. N. (2015). Critical success factors in merger \& acquisition strategies: Evolution of Turkish market. Issletme Fakülte Dergisi, 16(2): 117-133.

Fu, F., Lin, L., \& Officer S, M. (2013). Acquisitions driven by stock overvaluation: Are they good deals? Journal of Financial Economics.

Genç, A., \& Coşkun, E. (2013). Birleşme ve satın alma duyurularında anormal getiri: Satın alan şirket ve hedef şirket açısından bir inceleme. Atatürk Üniversitesi Sosyal Bilimler Enstitüsü Dergisi, 17(3): 359-376.

Genç, Ö. (2016). Comparison of international and domestic acquisitions: A literature review. Yönetim ve Ekonomi Araştırmaları Dergisi, 14(4), 128-149. DOI: 10.11611/yead.282052

Genc, O.F., and Zakaria, R. (2017). A comparative analysis of international and domestic acquisitions: What drives acquirer competitiveness? J. Global Business Advancement, 10(5), 583-603

Gregory, A., \& Sheila. (2014). Do cross border and domestic acquisitions differ? Evidence from the acquisition of UK targets. International Review of Financial Analysis, 31(C), 61-69.

Gubbi, S. R., Aulakh, P. S., Ray, S., Sarkar, M. B., \& Chittoor, R. (2010). Do international acquisitions by emerging-economy firms create shareholder value? The case of Indian firms. Journal of International Business Studies, 41(3), 397-418.

İlarslan, K., \& Aşikoğlu. R. (2012). Birleşme ve satın almaların işletmelerin finansal performans1 üzerindeki etkilerinin incelenmesi: Panel veri analizi. Finans Politik ve Ekonomik Yorumlar, 49(572): 59-78.

Kogut, B., \& Zander, U. (1993). Knowledge of the Firm and the Evolutionary Theory of the Multinational Corporation. Journal of International Business Studies, 24(4), 625-645.

Malmendier, U., \& Tate, G. (2008). Who makes acquisitions? CEO overconfidence and the market's reaction. Journal of Financial Economics, 89(1), 20-43. doi: 10.1016/j. jfineco.2007.07.002

Semerciöz, F., \& Çakınberk, A. (2003). Stratejik ittifaklar: Türk ilaç dağıtım kanalından bir örnek. Yönetim Dergisi, 14 (46): 23-39.

Schiffbauer, M., Siedschlag, I., \& Ruane, F. (2017). Do foreign mergers and acquisitions boost firm productivity? International Business Review, 26(6), 1124-1140.

Spyrou, S., \& Siougle, G. (2007). Mergers and acquisitions of non-financial firms in Europe: The case of the Athens Stock Exchange. Applied Economics Letters, 14(7): 523-527. 
Şahin, A., \& Doğukanlı, H. (2015) Banka birleşme ve satınalma duyurularının hedef banka hisse senedi fiyatları üzerine etkileri. Finans Politik \& Ekonomik Yorumlar, 52(600): 9-25.

Tao, F., Liu, X., Gao, L., \& Xia, E. (2017). Do cross-border mergers and acquisitons increase short-term market performance? The case of Chinese firms. International Business Review, 26(1): 189-202.

Turgay, İ., Dördüncü, H., \& Tuncel, O. (2014). Havayolu sektöründe birleşme ve satın almaların mali dezavantajlarının örnek olay üzerinde incelenmesi. Trakya University Journal of Social Science, 16(1): 195-214.

World Investment Report. (2008).Transnational Corporations and Infrastructure Challange UNCTAD, New York and Geneva.

Yıldırım, C. (2017). Turkey' outward foreign direct Investment: Trends and patterns of mergers and acquisitions. Journal of Balkan and Near Eastern Studies, 19(3), 276-293. 
